\title{
Some thoughts on the physiology of caffeine in coffee - and a glimpse of metabolite profiling
}

\author{
Thomas W. Baumann \\ Institute of Plant Biology, University of Zurich, CH-8008 Zurich, Switzerland.E-mail: twb@botinst.unizh.ch
}

Human beings enjoy the flavor and stimulating activity of a cup of coffee without knowing that by doing so, they are part of a 'food web' and receive signals coffee plants build to improve their struggle for life. This review is centered in the first part on the purine alkaloid caffeine and its physiological role in the coffee plant's life cycle. Many of the thoughts and ideas presented here are plain speculation, because the real research revealing the secrets of plant physiology such as e.g. the formation of the coffee bean with all its ingredients, has just started. The recent achievements in molecular biology made it possible to tackle and answer new questions regarding the regulation of secondary metabolism in the coffee plant organs at selected stages of their development. Brazilian research groups have much contributed to the recent progress in molecular biology and physiology of coffee. Among them was Maro R. Söndahl, in commemoration of whom this article has been written. Thus, the second part reports on the very first steps Maro and I made together into a very new field of coffee, that is metabolite profiling. The outcome was amazing and gives an idea of the great potential of this technique to map in future the complex network of the coffee metabolom.

Key words: Endosperm, flower, germination, metabolite profiling, purine alkaloid, perisperm.

\begin{abstract}
Alguns pensamentos sobre a fisiologia da cafeína em café - e uma rápida olhada no perfil metabólico: Humanos apreciam o sabor e a estimulante atividade de uma xícara de café sem saber que fazendo isto, eles fazem parte de uma teia alimentar e recebem sinais de plantas de café criados para melhorar sua sobrevivência. Esta revisão tem sua primeira parte centrada no alcalóide purínico cafeína e seu papel fisiológico no ciclo de vida da planta de café. Muitas das considerações e idéias apresentadas aqui são especulações, porque a pesquisa verdadeira revelando os segredos da fisiologia da planta de café, tal como a formação da semente de café com todos seus ingredientes, apenas começou recentemente. Os resultados recentes na biologia molecular tornou possível controlar e responder novas questões relatives à regulação do metabolismo secundário nos órgãos de plantas de café em estádios específicos de seu desenvolvimento. Grupos brasileiros de pesquisa contribuiram significativamente para o recente progresso em biologia molecular e fisiologia do café. Entre eles inclui-se Maro R. Söndahl, para quem este artigo é dedicado. Assim, a segunda parte deste artigo relata sobre os primeiros passos que Maro e eu fizemos juntos em uma área muito nova em café, que é o perfil metabólico. Os resultados foram surpreendentes e fornecem novas idéias para o grande potencial desta técnica para mapear futuramente a complexa rede do metaboloma do café.
\end{abstract}

Palavras-chave: Alcalóides purínicos, endosperma, flor, germinação, perfil metabólico, perisperma.

\section{Introduction}

Prologue: Originally, the title intended for this review was 'The physiological role of alkaloids in coffee'. However, two facts induced me to abandon it. One is their multitude ${ }^{1}$ and the other the still poor record in literature regarding their physiological role in plant life - of course, except for the prominent favorites caffeine and trigonelline. Thus, this review will be restricted more or less to the purine alkaloids.
However, I take the commemorative opportunity to report on one aspect of his last work Maro R. Söndahl initiated with me at the University of Zurich, which, quite unexpectedly, led to metabolite profiling. Finally, I should mention that the present article cannot be comprehensive. Therefore, the interested reader is referred to related reviews in this field (Ashihara and Suzuki, 2004; Kato and Mizuno, 2004; Mazzafera, 2004).

\footnotetext{
${ }^{1}$ In a wide sense 'alkaloids' may include - with the exception of free amino acids, of peptides and proteins - all organic compounds containing nitrogen and thus would comprise not only heterocycles such as e.g. derivatives of purines, pyrimidines or pyridines but also free and conjugated amines or amides as well as conjugated amino acids. To my knowledge there is no compilation in literature on this subject. Very remarkable, however, is the plethora of almost 40 volatile alkaloids so far detected in the green coffee bean and ranging from aromatic amines via pyridines and pyrazines to quinolines (Vitzthum, 1975; Holscher and Steinhart, 1995).
} 
Concept and terms: Almost 120 years ago, Ernst Stahl (18481919), Professor of Botany in Jena, Germany, formulated the concept of chemical defence as a result of animal/plant interactions. In 1888 he wrote (Stahl, 1888): "Nobody doubts that plants developed morphological features towards animals during their struggle for life. This is especially evident by the great diversity of flower forms. In the same sense one should interpret the multitude of phytochemicals, namely, that the animal kingdom affected not only the morphology but also the chemistry of the plant." (translated from Ger$\operatorname{man}^{2}$ ). Only 3 years later, the German Albrecht Kossel (18531927), who received in 1910 the Nobel prize of medicine (http://www.nobel.se/medicine/laureates/1910/index.html) for his work on the chemistry of the cell nucleus, introduced the terms 'primary' and 'secondary' metabolites (1891): "The chemistry should attempt to isolate those components which are present without exception in a protoplasma with developmental capacity, and to reveal the other cell components which are casual or not absolutely necessary for life... I propose to designate these essential cell compounds as primary, whereas those, which cannot be found in every developmentally competent cell, as secondary." (translated from $\mathrm{German}^{3}$ ). It has to be mentioned that Kossel was also the first who isolated theophylline from nature (Kossel, 1888, 1889)! Kurt Mothes (1900-1983), a pioneer in the field of plant secondary metabolism considered the formation and accumulation of alkaloids in first line as a lack of plants to excrete them - in contrast to animals. However, he accepts their ecological function in certain cases, where the avoidance by all predators is clearly recognized, e.g. Aconitum or Veratrum in alpine regions, but generally refuses utilitarian views when looking at the 'play of nature' (Mothes, 1965). Indeed, at that time there was little scientific proof regarding the significance of secondary substances for plant life, not to speak of for the entire web of organisms. However, progress made with respect to their translocation, subcellular compartmentation, and allocation to the risk of predation, and last but not least insights into their specific targets in animal metabolism have led to a modern chemical approach to systems biology in which also the Homo sapiens has been included. There is no doubt, that secondary compounds greatly influence the human physiology and by interacting with receptors modify human performance and behavior as e.g. experienced by generations in the case of caffeine (Fisone et al., 2004; Cauli and Morelli, 2005).

Allocation patterns: The knowledge about allocation in space and time is indispensable to reveal the role of a phytochemical in nature. The above-mentioned pioneers in phytochemistry might have thought themselves fortunate when reporting on the overall content of a plant substance. Today, the questions regarding the allocation of a phytochemical are distinctly differentiated and are put - besides 'how much per plant mass?' - as follows: 'where?' (organ, tissue, individual cells, cell compartment), 'when?' (developmental stage, induction by what means), 'from where?' (short- or long-distance transport), and last but not least ' 'how?'. Such an advanced and holistic view implies, apart from a broad knowledge in botany and plant physiology, the use of a wide array of various techniques and tools such as HPLC, tracer feeding, immunology, tissue and cell fractionation, diverse microscopic techniques, enzymology, and last but not least molecular biology. Related sophisticated work on coffee is still rare, but recent metabolic and molecular studies (Rogers et al., 1999; Geromel et al., 2004; Melo and Mazzafera, 2004) regarding the perisperm-endosperm transition (see below) are very promising. Since, as outlined before, caffeine and its allies are by far the best investigated compounds in coffee, I will take them as an example to illustrate in the following their physiology through the coffee plant life, from germination via leaf formation and branching to flowering and seed production. Before going into details one should mention that the physiological role of alkaloids has two facets in general: One is allocation to the reproductive organs, i.e. flowers and seeds, eventually yielding the dispersal unit, the so-called diaspore (van der Pijl, 1982), equipped with a genetically fixed, species-specific alkaloid pattern not immediately influenced by external factors. The other represents the dynamic and plastic events in the vegetative plant parts such as leaves, roots and shoots, greatly affected by and directed towards all kind of biotic and abiotic factors. Hence, alkaloids - or in a wider sense phytochemicals - help the individual to survive and the species to evolve.

\footnotetext{
2 "Niemand zweifelt daran, dass die Pflanzen in ihrem Daseinskampf mit der Tierwelt morphologische Besonderheiten entwickelten. Besonders auffällig tritt dies zutage in der Mannigfaltigkeit der Blütenbildungen. Im gleichen Sinne muss die Vielfalt der Pflanzenstoffe verstanden werden, nämlich dass die Tierwelt nicht nur die Morphologie, sondern in besonderem Masse auch die Chemie der Pflanze beeinflusste."

3 "Die Chemie muss versuchen, diejenigen Bestandteile herauszusondern, die in dem entwicklungsfähigen Protoplasma ohne Ausnahme vorhanden sind und die zufälligen oder für das Leben nicht unbedingt nötigen Zellstoffe als solche zu erkennen..... Ich schlage vor, diese wesentlichen Bestandteile der Zelle als primäre zu bezeichnen, hingegen diejenigen, welche nicht in jeder entwicklungsfähigen Zelle gefunden werden, als sekundäre."
} 


\section{Purine alkaloids}

Generally, they comprise on the one side the methylxanthines caffeine, theobromine, theophylline, and paraxanthine, and on the other side the methyluric acids theacrine, liberine, and methylliberine. However, we also should include the biosynthetic precursors of methylxanthines such as monomethylxanthines, methylated nucleosides or nucleotides. Moreover, one may expect many other methylated uric acids at very low concentrations.

Germination: It is perhaps the most critical event in a plant's lifecycle, not only because of a sudden exposure of the emerging seedling to competition, predation and diseases but also to the risk of an abrupt change of the physical conditions which had allowed the initiation of the germination process. With respect to their germination behavior, coffee seeds are intermediate meaning that they are cold-sensitive and show a certain degree of dormancy but only a partial desiccation tolerance (Ellis et al., 1990, 1991). A most intriguing fact is that only less than $0.1 \%$ of total caffeine escapes from the seed during imbibition (Baumann and Gabriel, 1984), most likely as the result of an effective diffusion barrier by cell wall-bound phenolics such as chlorogenic acids (Dentan, 1985). However, the participation of high-affinity purine transporters cannot be ruled out. In essence, during imbibing of water the coffee bean avoids loss of, and simultaneously prevents autotoxicity by caffeine (Mösli Waldhauser and Baumann, 1996) - an act of balance certainly impaired by cryopreservation and possibly 'repaired' by postthawing osmoconditioning (Dussert et al., 2000; Dussert et al., 2003). Seemingly, low-caffeine coffee species are better candidates for cryopreservation (Dussert et al., 1998). It has to be shown whether this is also true for the arabica mutant laurina or the recently discovered caffeine-free mutant (Silvarolla et al., 2000; Silvarolla et al., 2004). The caffeine barrier may also be of significance during diaspore dispersion (van der Pijl, 1982) as shown for the guaraná seed (Baumann et al., 1995), where it efficiently prevents intoxication of the arildigesting toucans by resisting even to the conditions of the digestive tract. Coffee-dispersing animals (birds, mammals) swallowing the diaspore with or without the pulp would - in the absence of the 'caffeine shield' - suffer from intoxication, since the digestion-resistant endocarp is permeable for caffeine.

During the subsequent onset of germination of $C$. arabica which is optimal at $25-27^{\circ} \mathrm{C}$ and characterized by the emergence of the primary root, much caffeine is found outside the seedling, most likely as a result of a release through the primary root (Baumann and Gabriel, 1984; Aerts and Baumann, 1994). Unfortunately, the mechanism and exact location of this event has never been studied in detail. Caffeine is like many other secondary compounds multifunctional and acts against a wide array of organisms in a very specific manner (table 1).

The role of caffeine exudation by the root could be explained by its allelopathic effect knocking out competing seeds or young seedlings in the vicinity of the germinating bean (Ransom, 1912a, 1912b). However, since this methylxanthine is rapidly catabolized by soil-borne microorgansims, it is unlikely to have such a distant effect. Speculatively, together with other excreted phytochemicals it rather helps the young seedling to establish and 'condition' the rhizosphere i.e. to create an optimum microbial and physical environment for plant development facilitating mycorrhiza formation and supporting the fight against 'underground attackers' such as nematodes.

Germination - until the cotyledons are unfolded and fully expanded - lasts about ten weeks. During the first 2 to 3 weeks the primary root and the hypocotyl emerge from the seed, and the cotyledons have already started to invade and resorb the endosperm, a process finished after 5 weeks of germination. Clearly, the metabolites of the cellularized endosperm are shuffled via the apoplast into the cotyledons. Unfortunately, little is known about the related apoplastic transport, i.e. the extent of diffusion, the impact of transporters and not to speak of the regulating 'communication at the synapsis' between cotyledons and endosperm. Non-destructive probing of coffee beans and analysis of the subsequently emerging cotyledons revealed, that the latter are with respect to caffeine not more than a 'simple blot' of the endosperm (Baumann et al., 1998). Thus, caffeine is neither degraded nor additionally formed during invasion by and development of the cotyledons. Also later in plant development, they seem to be metabolically cut off from the rest of the plant, most clearly seen in the liberio-excelsoid coffees, in which the newly formed foliage leaves start to transform caffeine into methylated uric acids (Petermann and Baumann, 1983) whereas the cotyledons preserve the caffeine until shedding, i.e. after several months after their development (Baumann et al., 1976).

Foliage leaf development: After about 5 weeks the arabica leaf is fully expanded but with a leaf blade still soft and glossy. Two to 3 weeks later, the leaf has attained its maxi- 
mum dry weight and the now dull lamina its final rigidity. The entire development may be sectioned into the following stages: the quiescent bud, (b) emergence from the bud, (c) lamina expansion and mechanical strengthening, and (d) senescence. The time-course of formation and allocation of caffeine has been recently reviewed (Söndahl and Baumann, 2001) and is summarized as follows: Since the leaf primordia in the bud are mechanically protected by a resinous layer and two firm stipules, chemical defence by $\mathrm{PuA}$ is not very significant as can be recognised by a wide variation of alkaloid concentration from bud to bud. However, as soon as the leaflets develop and push apart the stipules, their concentration sharply increases and attains a level of up to $4 \%$ with a decreasing coefficient of variation signifying that chemical defense by purine alkaloids has become a crucial and very stringent factor, when the soft leaflets are fully exposed to the physical and biotic environment. At that time, the activities of the involved methyltransferases exhibit a peak level and the velocity of caffeine biosynthesis $\left(17,000 \mu \mathrm{g}\right.$.day $\left.{ }^{-1} \cdot \mathrm{g}^{-1}\right)$ is highest. Interestingly, high caffeine formation rate is always accompanied by relatively high levels of theobromine as if the last methylation were rate limiting. During further expansion, enzyme activities decrease exponentially and caffeine formation slows down by a factor of 1,000. The caffeine concentration basically drops as a consequence of 'dilution by growth'. However, the absolute amount of caffeine increases steadily, because of low enzyme activities persisting throughout the entire period of leaf expansion (Mösli Waldhauser et al., 1997). Simultaneously, the nutritional value of the leaf decreases while the mechanical strength of the leaf increases indicating altogether a fitness-orientated regulatory background. We should finally mention that during leaf development the chlorogenic acids are allocated in parallel to the purine alkaloids (Aerts and Baumann, 1994). The activity of the key enzyme of phenylpropane synthesis, phenylalanine ammonia lyase (PAL), is very high in the young leaflets and decreases during the further expansion (Aerts and Baumann, 1994), this coinciding with the time course of NMTs catalysing caffeine biosynthesis. The concerted formation of both the alkaloids (mainly caffeine) and chlorogenic acids (mainly 5-caffeoylquinic acid; 5-CQA) has a physiological significance: caffeine, which easily permeates through all kind of biological barriers, is physico-chemically complexed by 5-CQA and thus compartmented in the cellular vacuole in order to avoid autotoxicity (Mösli Waldhauser and Baumann, 1996). However, these processes eventually result in a coffee leaf with a lamina in which these phytochemicals are not evenly distributed. Preliminary investigations (Wenger and Baumann, unpublished) revealed that both chlorogenic acids and purine alkaloids are considerably

Table 1. Organism-related effects of caffeine (multifunctionality)

\begin{tabular}{|c|c|c|c|}
\hline Organism & Effect & Underlying Mechanism, Target & References \\
\hline Bacteria \& Fungi (yeasts) & bacterio- and fungistatic & inhibits 'UV dark repair' in DNA & $\begin{array}{l}\text { (Kihlman, 1977; McCready et } \\
\text { al., 2000) }\end{array}$ \\
\hline Fungi & $\begin{array}{l}\text { fungistatic, reduces mycotoxin } \\
\text { production }\end{array}$ & not known & (Buchanan et al., 1981) \\
\hline Plants & $\begin{array}{l}\text { inhibits germination, reduces } \\
\text { growth }\end{array}$ & $\begin{array}{l}\text { not known; inhibits the formation } \\
\text { of the cell plate, calcium? }\end{array}$ & $\begin{array}{l}\text { (Gimenez-Martin et al., 1968; } \\
\text { Rizvi et al., 1981) }\end{array}$ \\
\hline Molluscs (snails \& slugs) & molluscicidal, reduces heart rate & $\begin{array}{l}\text { calcium release, increases the } \\
\text { duration of action-potential } \\
\text { plateaus? }\end{array}$ & (Hollingsworth et al., 2002) \\
\hline Insects $^{4}$ & disturbs developmental processes & $\begin{array}{l}\text { inhibits cyclic AMP } \\
\text { phosphodiesterase }\end{array}$ & (Nathanson, 1984) \\
\hline Mammals & $\begin{array}{l}\text { activates CNS, constriction of the } \\
\text { cerebral blood vessels, increases } \\
\text { lipolysis, positive inotropic }\end{array}$ & binds to adenosine receptors & (Nehlig, 1999) \\
\hline
\end{tabular}

\footnotetext{
${ }^{4}$ It should be mentioned, that purine alkaloids are directed against generalists and that many specialists not only tolerate these compounds but even may have a benefit of them: leaf miner and coffee borer are highly adapted to caffeine (Guerreiro and Mazzafera, 2000, 2003), whereas honeybees show signs of beneficial activation by this methylxanthine (Ishay and Paniry, 1979; Singaravelan et al., 2005).
} 
enriched at the leaf margin and sharply decrease in concentration towards the midvein. Conceivably, this phytochemical leaf architecture has an ecological significance: the leaf margin, a preferential site of insect attack, is particularly well furnished with these defence compounds. If the margin is cut away, caffeine biosynthesis is induced and after formation of xanthine, theobromine, etc., a new 'phytochemical margin' is established. However, the induction of chlorogenic acid biosynthesis after wounding has not been studied. Is the phytochemical architecture of the leaf genetically fixed, or in other words, do mutants exist with an inverse alkaloid distribution? Based upon the free mobility of purine alkaloids through all kind of barriers (except the diaspore surface) and the in situ complexation by chlorogenic acids, we may hypothesize that caffeine and its allies are distributed within the plant to the extent of CGA formation and accumulation. Thus, the allocation pattern of the latter may govern the direction and the rate of caffeine fluxes within the coffee plant. Since the complexor concentration is highest in the newly formed organs e.g. in the young leaves and internodes (Zheng and Ashihara, 2004) as well as in young fruits, it may explain the observed translocation of caffeine in the xylem sap (Mazzafera and Goncalves, 1999), from old to young leaves or from the pericarp into the developing seed (Baumann and Wanner, 1972). However, active transporters for purines (Gillissen et al., 2000; Burkle et al., 2003) may accelerate long distance displacement of caffeine.

Leaf senescence: It is not yet clear to which extent the arabica plant recovers the caffeine nitrogen from the senescing leaf. In his pioneering studies, Weevers analysed leaves of various age collected from plants in the greenhouse in Amsterdam and noticed a decrease of the caffeine content by $50 \%$ at the most (Weevers, 1907). However, leaf longevity and seasonal variation of greenhouse conditions may explain the discrepancy between 'adult' and 'old' simply as a result of different life histories. Since caffeine-degrading microorganisms are expected to be part of the plant surface as well as of the endophytic microflora, all reports dealing with degradation or with the time-course of the caffeine concentration in aging leaves must be considered with caution, unless the absence of endophytes was proven and other microbial interferences were excluded. In our own studies (Huber and Baumann, unpublished) we were not able to find distinctly lower caffeine levels in shed arabica leaves even when yellow! Of course, substantial degradation of caffeine occurs in liberio-excelsoid coffee leaves even when young (Petermann and Baumann, 1983; Mazzafera et al., 1994; Mazzafera, 2004).
Flowering: Despite much research done on the metabolism during coffee flower development, see e.g. (Vasudeva and Gopal, 1977), the aspect of purine alkaloid allocation is to our knowledge not yet mentioned in literature. I can report here solely on a few analyses we did on petals, stamens and the gynoecium in arabica flowers at anthesis: All these flower parts contained caffeine as main purine alkaloid, around 3000 nmol.g $\mathrm{g}^{-1} \mathrm{FW}$ in petals and gynoecium, and around 7000 nmol.g-1 $\mathrm{FW}$ in stamens. Whereas the gynoecium had a large fraction of theobromine (10 to $20 \%$ of caffeine) and nil theophylline, the other organs had remarkably high theophylline values, that is $4-12 \%$ of caffeine and less than $1 \%$ theobromine, indicating that in petals and stamens (and pollen) caffeine is synthesized via theophylline like in Citrus (Stutz, 2001). If we combine all the data available on purine alkaloids in flowers of 'caffeine plants', that is from literature (Suzuki, 1985; Fujimori and Ashihara, 1990, 1993; Tretyn et al., 1994; Kretschmar and Baumann, 1999; Lin et al., 2003; Weckerle et al., 2003; Naef et al., 2004; Jin et al., 2005) and from our own, not yet published studies (Stutz, 2001), one may conclude the following: (a) Species with high alkaloid levels in leaves and axes such as Coffea arabica, Paullinia cupana, Camellia sinensis exhibit relatively high concentrations in all corolla parts, whereas (b) species with very low alkaloid concentrations in the vegetative parts such as Citrus spp, Poncirus trifoliata, Murraya paniculata, Theobroma cacao, T. grandiflorum, Cola humilis and perhaps also Tilia cordata, allocate the alkaloids within the flower exclusively to the stamens; staminodes if present are alkaloid-free. It has to be mentioned that also the nectar, as far as analyzed, contains purine alkaloids. Does the pattern in (b) signify an efficient and specific chemical defence of the male sex against pollen robbery and/or the favoring of certain pollinators such as honey bees not only tolerant against (Detzel and Wink, 1993) but also preferring purine alkaloids (Singaravelan et al., 2005), known to improve insect performance (Ishay and Paniry, 1979)? Since the average alkaloid concentration in both leaves and flowers is very low, one may speculate that in these species leaf purine alkaloid accumulation is likewise restricted to specific sites such as e.g. the wax layer or idioblasts.

Fruit and seed development: After blossom fall, the remaining ovary develops, under favorable conditions, without delay into the young, rapidly growing green coffee bean which, due to high investments, is protected against predators by several means: The fruits are inapparently clustered in the leaf axil; both chlorogenic acids and purine alkaloids are highly 
concentrated in the pericarp, and finally, the development of the true, nutrient rich endosperm is postponed in favor of a 'maternal bean' (Carvalho et al., 1969), made out of perisperm and reaching in arabica within 3 to 4 months after anthesis almost the size of the true bean . Seemingly, the mother avoids the 'parental conflict' (Barton et al., 1984; Haig and Westoby, 1989) by establishing a placeholder, the 'perisperm bean', and by this acts like a handicapper decreeing several parameters: The size of the cavity for the latter endosperm bean, the amount of phosphate to be used (West et al., 1995), the velocity of embryo differentiation (Borisjuk et al., 2004), i.e. the pathways of sugar-signaling by a specific sugar pattern (Rogers et al., 1999; Geromel et al., 2004), the amount of carbon (energy) sources for development and last but not least, the extent of chemical defence by allocation of secondary compounds or their precursors such as e.g. quinic acid (Rogers et al., 1999). Clearly, the endosperm - invading the perisperm from the adaxial pole and literally resorbing it - has its own biosynthetic capacities and in addition gets metabolic support by the pericarp. Therefore, the endosperm is not a simple 'blot' of the perisperm as it has been shown at least for caffeine during the endosperm/cotyledon transition (Baumann et al., 1998). Nevertheless, the metabolites have to be shuffled via the apoplast, generally furnished with a remarkable armada of hydrolytic enzymes. Presumably, the metabolic passage from perisperm into endosperm is besides simple diffusion a highly regulated translocater-assisted process, firmly coordinated with on-the-spot synthesis as well as with import from other sources. It is one of the most intriguing tasks of the coffee research to explore all the metabolic and regulatory events finally culminating in a coffee bean furnished with a cocktail of substances yielding a pleasant and unique mix after roasting.

Now, back to caffeine! Its final amount and concentration in the true bean is the result of (a) acquisition from the perisperm, (b) intrinsic biosynthesis as shown by tracer experiments (Keller et al., 1972) and enzymatic studies (Mazzafera et al., 1994; Mizuno et al., 2003), and (c) import from the pericarp as demonstrated by doubly labelled caffeine (Baumann and Wanner, 1972). It may well be, that the extent of (a) and (c) is governed in essence, as outlined above, by the allocation of chlorogenic acids. Hence, the regulation of the pathways of these depsides is of key importance. Mazzafera's group recently showed by RT-PCR, that all the genes coding for chlorogenic acid synthesis are strongly expressed during endosperm development and gradually decline towards maturity (Melo and Mazzafera, 2004). The concentration of chlorogenic acids was, as expected, highest at the youngest stage. With respect to the time course of caffeine accumulation in the developing fruit, I refer to the work of (Keller et al., 1972; Marraccini et al., 2001).

\section{Metabolite profiling}

Maro R. Söndahl, to whom this issue is dedicated, was much concerned about coffee quality and especially about the question whether classical breeding could negatively influence the coffee metabolom, such as introducing new compounds as compared with arabica, the 'standard of excellence'. Since at that time (1998) no reports existed on this subject, we firstly decided to established a sophisticated, highly reproducible HPLC system, just in order to separate in one run as much metabolites as possible, and to determine the quantity as well as the UV spectra of all of them. Coffee beans from seven entities (species, varieties, or interspecific crosses) were extracted and analysed. More than $100 \mathrm{UV}$ absorbing substances per sample could be resolved and absolutely or, if unknown, relatively quantified. The data were analysed using a correlation program and essentially yielded the following new insights, which were neither intended nor expected:

(1) Trigonelline negatively correlated with caffeine, i.e. high caffeine values were accompanied by low trigonelline values and vice versa, indicating a close but competing linkage of the two pathways. This reminds on the hypothesis of Kremers postulating a common origin of both caffeine and trigonelline in the coenzymes NAD/ NADP (Kremers, 1954). With the today knowledge one could extend the link further to the poly(ADPribose) metabolism (Berglund, 1994; De Block et al., 2005; Diefenbach and Burkle, 2005). Of course, the competition for methyl groups is more obvious and less speculative.

(2) Caffeine correlated not with 5-CQA, but highly with minor chlorogenic acids primarily including di-CQAs. This finding contradicts somehow the general opinion of 5-CQA being the most important caffeine complexor (Horman and Viani, 1972; Mösli Waldhauser and Baumann, 1996). Additionally, a close look to the data revealed that the minor chlorogenic acids altogether were in molar equivalence to caffeine as if they were physically engaged in the complex without participating at the equilibrium with 5-CQA. Or in other words, each caffeine molecule seemingly has a minor CQA, most likely a di-CQA companion, which may be involved either in the 1:1 complex or in the transport of caffeine 
to its location, or in both. During endosperm maturation the content of di-CQAs is adjusted: In its final phase their amount drops in arabica in relation to the other CQAs (De Menezes, 1994). Much more pronounced is this process in the caffeine-free C. pseudozanguebariae, where at the beginning of endosperm development diCQAs account for $25 \%$ of all chlorogenic acids and completely have 'disappeared' when mature (Bertrand et al., 2003). Are the di-CQAs in arabica and robusta protected from degradation because they form with caffeine and by the help of the two caffeoyl residues a stable, sandwich-like complex? Or, since the di-CQAs have not a good reputation regarding the aroma, one could ask the other way around: Does the bean caffeine only feel well in bad company? The half-caffeine laurina with a normal 5-CQA (Carelli et al., 1974), but a reduced minor CGA content is famous for its excellent aroma (Söndahl et al., 1995; Le Pièrres, 2001). Thus, the sensational discovery of the caffeine-free arabica mutant (Silvarolla et al., 2004) may lead to an exciting olfactory sensation!

\section{LITERATURE}

Aerts RJ, Baumann TW (1994) Distribution and utilization of chlorogenic acid in Coffea seedlings. J. Exp. Bot. 45: 497-503

Ashihara H, Suzuki T (2004) Distribution and biosynthesis of caffeine in plants. Front. Biosc. 9: 1864-1876

Barton SC, Surani MAH, Norris ML (1984) Role of paternal and maternal genomes in mouse development. Nature 311: 374-376

Baumann TW, Gabriel H (1984) Metabolism and excretion of caffeine during germination of Coffea arabica L. Plant Cell Physiol. 25: 1431-1436

Baumann TW, Oechslin M, Wanner H (1976) Coffein und methylierte Harnsären: Chemische Muster wärend der vegetativen Entwicklung von Coffea liberica. Biochem. Physiol. Pflanzen 170: 217-225

Baumann TW, Schulthess BH, Häni K (1995) Guarana (Paullinia cupana) rewards seed dispersers without intoxicating them by caffeine. Phytochemistry 39: 1063-1070

Baumann TW, Söndahl MR, Waldhauser SSM, Kretschmar JA (1998) Non-destructive analysis of natural variability in bean caffeine content of Laurina coffee. Phytochemistry 49: 1569-1573

Baumann TW, Wanner H (1972) Untersuchungen über den Transport von Kaffein in der Kaffeepflanze (Coffea arabica). Planta 108: 11-20

Berglund T (1994) Nicotinamide, a missing link in the early stress-response in eukaryotic cells - A hypothesis with special reference to oxidative stress in plants. Febs Lett. 351: $145-149$
Bertrand C, Noirot M, Doulbeau S, de Kochko A, Hamon S, Campa C (2003) Chlorogenic acid content swap during fruit maturation in Coffea pseudozanguebariae - Qualitative comparison with leaves. Plant Sci. 165: 1355-1361

Borisjuk L, Rolletschek H, Radchuk R, Weschke W, Wobus U, Weber H (2004) Seed development and differentiation: A role for metabolic regulation. Plant Biol. 6: 375-386

Buchanan RL, Tice G, Marino D (1981) Caffeine inhibition of ochratoxin A production. J. Food Sci. 47: 319-321

Burkle L, Cedzich A, Dopke C, Stransky H, Okumoto S, Gillissen B, Kuhn C, Frommer WB (2003) Transport of cytokinins mediated by purine transporters of the PUP family expressed in phloem, hydathodes, and pollen of Arabidopsis. Plant J. 34: 13-26

Carvalho AC, Ferwerda FP, et al. (1969) Coffee. In: Ferwerda FP, Wit F (eds), Reprinted from: Outlines of perennial crop breeding in the tropics, Vol Miscellaneous papers No. 4, pp.189-241. Landbouwhogschool (Agricultural University), Wageningen, The Netherlands.

Cauli O, Morelli M (2005) Caffeine and the dopaminergic system. Behav. Pharmacol. 16: 63-77

De Block M, Verduyn C, De Brouwer D, Cornelissen M (2005) Poly(ADP-ribose) polymerase in plants affects energy homeostasis, cell death and stress tolerance. Plant J. 41: 95-106

De Menezes HC (1994) The relationship between the state of maturity of raw coffee beans and the isomers of caffeoylquinic acid. Food Chem. 50: 293-296

Dentan E (1985) The microscopic structure of the coffee bean. In: Clifford MN, Willson KC (eds), Coffee: botany, biochemistry, and production of beans and beverage, pp. 284304. Croom Helm, London.

Detzel A, Wink M (1993) Attraction, deterrence or intoxication of bees. Chemoecology 4: 8-18

Diefenbach J, Burkle A (2005) Introduction to poly(ADP-ribose) metabolism. Cell. Mol Life Sci. 62: 721-730

Dussert S, Chabrillange N, Engelmann F, Anthony F, Louarn J, Hamon S (1998) Cryopreservation of seeds of four coffee species (Coffea arabica, C-costatifructa, C-racemosa and C-sessiliflora): importance of water content and cooling rate. Seed Sci. Res. 8: 9-15

Dussert S, Chabrillange N, Montillet JL, Agnel JP, Engelmann F, Noirot M (2003) Basis of coffee seed sensitivity to liquid nitrogen exposure: oxidative stress or imbibitional damage? Physiol. Plant. 119: 534-543

Dussert S, Chabrillange N, Vasquez N, Engelmann F, Anthony F, Guyot A, Hamon S (2000) Beneficial effect of postthawing osmoconditioning on the recovery of cryopreserved coffee (Coffea arabica L.) seeds. Cryo-Lett. 21: 47-52

Ellis RH, Hong TD, Roberts EH (1990) An Intermediate Category of Seed Storage Behavior.1. Coffee. J. Exp. Bot. 41: 1167-1174

Ellis RH, Hong TD, Roberts EH (1991) An Intermediate Category of Seed Storage Behavior.2. Effects of Provenance, Immaturity, and Imbibition on Desiccation-Tolerance in Coffee. J. Exp. Bot. 42: 653-657

Fisone G, Borgkvist A, Usiello A (2004) Caffeine as a psychomotor stimulant: mechanism of action. Cell. Mol. Life Sci. 61: $857-872$ 
Fujimori N, Ashihara H (1990) Adenine metabolism and the synthesis of purine alkaloids in flowers of Camellia. Phytochemistry $29: 3513-3516$

Fujimori N, Ashihara H (1993) Biosynthesis of caffeine in flower buds of Camellia sinensis. Ann. Bot. 71: 279-284

Geromel C, Ferreira LP, Cavalari AA, Pereira LFP, Vieira LGE, Leroy T, Mazzafera P, Marraccini P (2004) Sugar metabolism during coffee fruit development. In: XX International Conference on Coffee Science. Bangalore, CDrom.

Gillissen B, Burkle L, Andre B, Kuhn C, Rentsch D, Brandl B, Frommer WB (2000) A new family of high-affinity transporters for adenine, cytosine, and purine derivatives in arabidopsis. Plant Cell 12: 291-300

Gimenez-Martin G, Lopez-Saez JF, Moreno P, Gonzalez-Fernandez A (1968) On the triggering of mitosis and the division cycle of polynucleate cells. Chromosoma 25: 282-296

Guerreiro O, Mazzafera P (2000) Caffeine does not protect coffee against the leaf miner Perileucoptera coffeella. J. Chem. Ecol. 26: 1447-1464

Guerreiro O, Mazzafera P (2003) Caffeine and resistance of coffee to the berry borer Hypothenemus hampei (Coleoptera: Scolytidae). J. Agric. Food Chem. 51: 6987-6991

Haig D, Westoby M (1989) Parent-Specific Gene-Expression and the Triploid Endosperm. Am. Natur. 134: 147-155

Hollingsworth RG, Armstrong JW, Campbell E (2002) Caffeine as a repellent for slugs and snails. Nature 417: 915-916

Holscher W, Steinhart H (1995) Aroma compounds in green coffee. In: Charalambous G (ed), Food Flavors: generation, analysis and process influence, pp.785-803. Elsevier, Amsterdam.

Horman I, Viani R (1972) The nature and conformation of the caffeine-chlorogenate complex of coffee. J. Food Sci. 37: $925-927$

Ishay JS, Paniry VA (1979) Effects of caffeine and various xanthines on hornets and bees. Psychopharmacology 65: 299-309

Jin C, Wang PS, Xia YM, Xu M, Pei SJ (2005) Genetic diversity and differentiation of Camellia sinensis L. (cultivated tea) and its wild relatives in Yunnan province of China, revealed by morphology, biochemistry and allozyme studies. Gen. Res. Crop Evol. 52: 41-52

Kato M, Mizuno K (2004) Caffeine synthase and related methyltransferases in plants. Front. Biosci. 9: 1833-1842

Keller H, Wanner H, Baumann TW (1972) Kaffeinsynthese in früchten und gewebekulturen von Coffea arabica. Planta 108: $339-350$

Kihlman BA (1977) Caffeine and Chromosomes. Elsevier, Amsterdam

Kossel A (1888) Über eine neue Base aus dem Pflanzenreich. Chem. Ber. 21: 2164-2167

Kossel A (1889) Über das Theophyllin, einen neuen Bestandteil des Thees. Hoppe-Seyler's Zeitschrift Physiol. Chem. 13: 298-308

Kremers RE (1954) Speculation on DPN as a biochemical precursor of caffeine and trigonelline in coffee. J. Am. Pharm. Assoc.-Scientific Edition 43: 423-424

Kretschmar JA, Baumann TW (1999) Caffeine in Citrus flowers. Phytochemistry 52: 19-23
Lin YS, Wu SS, Lin JK (2003) Determination of tea polyphenols and caffeine in tea flowers (Camellia sinensis) and their hydroxyl radical scavenging and nitric oxide suppressing effects. J. Agric. Food Chem. 51: 975-980

Marraccini P, Allard C, Andre M-L, Courjault C, Gaborit C, Lacoste N, Meunier A, Michaux S, Petit V, Priyono P, Rogers JW, Deshayes A (2001) Update on coffee biochemical compounds, protein and gene expression during bean maturation and in other tissues. In: XIX Int. Sci. Colloq. Coffee. Trieste, CD-ROM.

Mazzafera P (2004) Catabolism of caffeine in plants and microorganisms. Front. Biosci. 9: 1348-1359

Mazzafera P, Crozier A, Sandberg G (1994) Studies on the metabolic control of caffeine turnover in developing endosperms and leaves of Coffea arabica and Coffea dewevrei. J. Agric. Food Chem. 42: 1423-1427

Mazzafera P, Goncalves KV (1999) Nitrogen compounds in the xylem sap of coffee. Phytochemistry 50: 383-386

McCready SJ, Osman F, Yasui A (2000) Repair of UV damage in the fission yeast Schizosaccharomyces pombe. Mut. Res. 451: 197-210

Melo GA, Mazzafera P (2004) Control of chlorogenic acid formation in leaves and endosperm of coffee fruit of Coffea arabica. In: XX International Conference on Coffee Science. Bangalore, CDrom.

Mizuno K, Okuda A, Kato M, Yoneyama N, Tanaka H, Ashihara H, Fujimura T (2003) Isolation of a new dual-functional caffeine synthase gene encoding an enzyme for the conversion of 7-methylxanthine to caffeine from coffee (Coffea arabica L.). FEBS Lett. 534: 75-81

Mothes K (1965) Bemerkungen zur Biologie der Alkaloide. In K Mothes, D Gross, H-W Liebisch, H-R Schütte, eds, 3. Internationales Symposium 'Biochemie und Physiologie der Alkaloide’, Vol Jahrgang 1966 Nr. 3. Akademie-Verlag, Halle (Saale), pp.27-34.

Mösli Waldhauser SS, Baumann TW (1996) Compartmentation of caffeine and related purine alkaloids depends exclusively on the physical chemistry of their vacuolar complex formation with chlorogenic acids. Phytochemistry 42: $985-996$

Mösli Waldhauser SS, Kretschmar JA, Baumann TW (1997) $\mathrm{N}$-methyltransferase activity in caffeine biosynthesis: biochemical characterisation and time course during leaf development of Coffea arabica. Phytochemistry 44: 853-859

Naef R, Jaquier A, Velluz A, Bachofen B (2004) From the linden flower to linden honey - Volatile constituents of linden nectar, the extract of bee-stomach and ripe honey. Chem. Biodiv. 1: 1870-1879

Nathanson JA (1984) Caffeine and related methylxanthines: possible naturally occurring pesticides. Science 226: $184-$ 187

Nehlig A (1999) Are we dependent upon coffee and caffeine? A review on human and animal data. Neuroscience and Biobehav. Rev. 23: 563-576

Petermann JB, Baumann TW (1983) Metabolic relations between methylxanthines and methyluric acids in Coffea L. Plant Physiol. 73: 961-964 
Ransom F (1912a) The effects of caffeine upon the germination and growth of seeds. Biochem. J. 6: 151-155

Ransom F (1912b) The action of caffeine upon the germination and growth of seeds. Biochem. J. 6: 156-161

Rizvi SJH, Mukerji D, Mathur SN (1981) Selective phyto-toxicity of 1,3,7-trimethylxanthine between Phaseolus mungo and some weeds. Agric. Biol. Chem. 45: 1255-1256

Rogers WJ, Michaux S, Bastin M, Bucheli P (1999) Changes to the content of sugars, sugar alcohols, myo-inositol, carboxylic acids and inorganic anions in developing grains from different varieties of Robusta (Coffea canephora) and Arabica (C. arabica) coffees. Plant Sci. 149: 115-123

Silvarolla MB, Mazzafera P, de Lima MMA (2000) Caffeine content of Ethiopian Coffea arabica beans. Gen. Mol. Biol. 23: 213-215

Silvarolla MB, Mazzafera P, Fazuoli LC (2004) Plant biochemistry - A naturally decaffeinated arabica coffee. Nature 429: 826-826

Singaravelan N, Nee'man G, Inbar M, Izhaki I (2005) Feeding responses of free-flying honeybees to secondary compounds mimicking floral nectars. J. Chem. Ecol. 31: 2791-2804

Söndahl MR, Baumann TW (2001) Agronomy II: Developmental and Cell Biology. In: Clarke RJ, Vitzthum OG (eds), Coffee recent developments, pp.202-223. Blackwell Science, London.

Stahl E (1888) Pflanzen und Schnecken: eine biologische Studie über die Schutzmittel der Pflanzen gegen Schnecken. Fischer, Jena
Stutz MA (2001) Purinalkaloide in Blüten. Zeitliche und rümliche Allokation. Aspekte der Biosynthese. Zurich, University of Zurich, MSc thesis.

Suzuki T (1985) Purine alkaloids in Camellia sinensis flowers. Agric. Biol. Chem. 49: 2803-2805

Tretyn A, Czaplewska J, Cymerski M, Kopcewicz J, Kendrick RE (1994) The mechanism of calcium action on flower induction in Pharbitis-Nil. J. Plant Physiol. 144: 562-568

van der Pijl L (1982) Principles of dispersal in higher plants, $3^{\text {rd }}$ edn. Springer-Verlag, Berlin

Vasudeva N, Gopal NH (1977) Physiological studies on flowering in coffee under South Indian conditions.7. Changes in iron and copper enzymes and ascorbic acid during flower bud development and anthesis. Turrialba 27: 355-359

Vitzthum OG (1975) Flüchtige Inhaltsstoffe des Rohkaffes. In: VII Int. Colloq. Coffee. Hamburg, pp.115-123

Weckerle CS, Stutz MA, Baumann TW (2003) Purine alkaloids in Paullinia. Phytochemistry 64: 735-742

Weevers T (1907) Die Funktion der Xanthinderivate im Pflanzenstoffwechsel. Arch. Neerl. Sci. IIIB 5: 111-195

West MM, Flannigan DT, Lott JNA (1995) Elemental composition of globoids in the perisperm tissue of various seeds. Can. J. Bot. 73: 954-957

Zheng XQ, Ashihara H (2004) Distribution, biosynthesis and function of purine and pyridine alkaloids in Coffea arabica seedlings. Plant Sci. 166: 807-813 